\title{
Cloning and Characterization of a Sucrose Phosphate Synthase-encoding Gene from Muskmelon
}

\author{
Xiyan Yu, Xiufeng Wang, Jide Fan, and Hongmei Tian \\ College of Horticulture Science and Engineering, Shandong Agricultural University, \\ Tai'an 271018, China \\ Chengchao Zheng ${ }^{1}$ \\ State Key Laboratory of Crop Biology, College of Life Sciences, Shandong Agricultural University, \\ Tai'an, Shandong 271018, China
}

\begin{abstract}
Additional INDEX words. Cucumis melo, CmSPS1, gene expression, sucrose metabolism
ABSTRACT. Sucrose phosphate synthase [SPS (EC 2.4.1.14)] is thought to play a critical role in sucrose accumulation in muskmelon (Cucumis melo $\mathrm{L}$.) fruit. A full-length cDNA clone encoding sucrose phosphate synthase was isolated from muskmelon by reverse transcriptase-polymerase chain reaction and rapid amplification of cDNA ends. The clone, designated CmSPS1, contains 3377 nucleotides with an open reading frame of 3162 nucleotides. The deduced 1054 amino acids sequence showed high identities with other plant sucrose phosphate synthases. Northern blot analysis indicated that CmSPS1 was expressed in leaves, stems, and mature fruit, but was not detected in roots or flowers. Moreover, the mRNA accumulation of CmSPS1 started at 25 days after pollination (DAP) and reached highest level in mature fruit. Interestingly, both sucrose content and SPS activity increased dramatically between 20 and 30 DAP during fruit development, suggesting that sucrose accumulation may be linked to the CmSPS1 transcript level in muskmelon fruit.
\end{abstract}

Sugars are the most important biochemical components for fruit quality. The kind and amount of sugars directly influence fruit flavor components such as sweetness. As the first step toward the genetic improvement of the quality of muskmelon fruit, it is necessary to determine the sugar components accumulated in fruit, elucidate enzymes involved in sugar metabolism, and clarify the relationship between the content of accumulated sugar and the activity of some related enzymes (McCollum et al., 1988; Moriguchi et al., 1992; Sakalo and Kurchii, 2004).

At the middle stage of fruit development, muskmelon fruit undergo a metabolic transition marked by both physical and compositional changes such as netting of the exocarp, mesocarp softening, and the onset of sucrose accumulation (Lester and Dunlap, 1985). Attempts to elucidate the changes in metabolism that lead to accumulation of sucrose have focused on sucrose-metabolizing enzymes during fruit growth and development (Geromel et al., 2006; Lingle and Dunlap, 1987; Schaffer et al., 1987; Winter and Huber, 2000). It was reported that both acid invertase (EC 3.2.1.26) and sucrose phosphate synthase (EC 2.4.1.14) are determinants of sucrose accumulation in melon fruit. However, the decline of the acid invertase appears to be a normal function of fruit maturation and is not the primary factor that determines sucrose accumulation. Rather, the capacity of sucrose synthesis, reflected in the sucrose phosphate synthase (SPS) activity, appears to determine

Received for publication 2 Dec. 2006. Accepted for publication 5 Apr. 2007. This work was supported by the National Natural Sciences Foundation (No. 30471191), Provincial Breeding Project of Shandong and Post Doctor Program Foundation of Shandong Agricultural University in China.

${ }^{1}$ Corresponding author. E-mail: cczheng@sdau.edu.cn. sucrose accumulation, which is a key component of fruit quality (Hubbard et al., 1989).

Recently, the SPS gene has been isolated from some higher plant species (Hesse et al., 1995; Hubbard et al., 1991; Huber and Huber, 1996; Li et al., 2003). In this report, we present the molecular cloning and characterization of CmSPS1 from muskmelon. In addition, the differential expression of CmSPS1 was determined in various tissues and fruit development stages of Cucumis melo.

\section{Materials and Methods}

Plant material and tissue sampling. Muskmelon inbred line M01-3 was grown in a greenhouse in an experimental farm of Shandong Agricultural University in Tai'an, China, from March through June 2006 with spacing $50 \mathrm{~cm}$ between plants and $120 \mathrm{~cm}$ between rows. Average day/night temperatures were $\approx 30 / 20{ }^{\circ} \mathrm{C}$. Average daylight was $\approx 12 \mathrm{~h}$. Fertilizer was applied at two stages, a preplant broadcast application of $900 \mathrm{~kg} \cdot \mathrm{ha}^{-1}$ of $14 \mathrm{~N}-6.1 \mathrm{P}-29.9 \mathrm{~K}$ followed by a sidedress application of $150 \mathrm{~kg} \cdot \mathrm{ha}^{-1} \mathrm{~N}$ at flowering stage. Irrigation by furrows was applied as needed. Freshly opened female flowers were tagged on the day of hand-pollination to identify fruit of known age and one fruit per plant was allowed to develop. Different developing stage $[5,10,15,20$, and $25 \mathrm{~d}$ after pollination (DAP)] and mature fruit were harvested. Thirty DAP is considered commercial maturity. Five fruit from each stage were pooled to isolate total RNA. A portion of each fruit was diced into small pieces and used for SPS activity assay and sucrose determination. The SPS activity assays and sucrose determination were carried out on duplicated samples. The experiments were repeated three times. For each replicate, five fruit were used. Vegetative tissues, including leaves, stems, and roots, were sampled along with 
flowers at bloom and harvested simultaneously from five 7- to 8 -week-old plants. All tissues were quickly frozen in liquid nitrogen and stored at $-80{ }^{\circ} \mathrm{C}$ until late use.

EXTRACTION AND PURIFICATION OF RNA. Total RNA was isolated using the guanidine isothiocyanate-phenol-chloroform method as described by Sambrook et al. (1989) with modification. Frozen tissue samples ( 5 to $10 \mathrm{~g}$ ) were ground to a powder in liquid $\mathrm{N}_{2}$ using a mortar and pestle. Samples of the homogenized, powdered tissue were transferred to $50-\mathrm{mL}$ screw-cap centrifuge tubes prechilled on ice followed by immediate addition of $15 \mathrm{~mL}$ solution D (4 M guanidine isothiocyanate, $0.025 \mathrm{M}$ trisodium citrate dehydrate, $0.5 \%$ lauryl sarcosine) and of $1.5 \mathrm{~mL}$ of $2 \mathrm{M}$ sodium acetate, $\mathrm{pH}$ $4.0,15 \mathrm{~mL}$ of phenol equilibrated with distilled water, and $3 \mathrm{~mL}$ of 49 chloroform: 1 isopropyl alcohol (v/v). After vortexing and incubation for $15 \mathrm{~min}$ on ice, the samples were processed according to Sambrook's method. The crude RNA preparations were then treated with DNase (TaKaRa Bio, Kyoto, Japan) to degrade genomic DNA, extracted with 1 phenol:1 chloroform (v/v), and total RNA was precipitated by addition of 1 volume isopropyl alcohol plus 0.1 volume of $3 \mathrm{M}$ sodium acetate, $\mathrm{pH}$ 5.5. The precipitated RNA was pelleted by centrifugation, washed with cold 70\% ethanol, and resuspended in diethyl pyrocarbonate-treated water. Quality of the extracted RNA was checked by agarose gel electrophoresis and RNA was quantified spectrophotomerically (ultraviolet 2450; Shimadzu Corp., Kyoto, Japan).

Cloning of CMSPS1 Complete CDNA. Total RNA isolated from 25 DAP fruit of $C$. melo M01-3 plants was used for the initial cloning of SPS cDNA fragments, including products of $3^{\prime}$ and 5' rapid amplification of cDNA ends (RACE). As the initial step in cloning a $C$. melo SPS gene, degenerate primers $\left(\mathrm{P}_{1}\right.$ : 5' -TCWAATCCAAGGAAGCCTATGA-3', $\mathrm{P}_{2}$ : 5' AACRGCGTGACAACGAAGT-3', $\mathrm{W}=\mathrm{T}+\mathrm{A}, \mathrm{R}=\mathrm{A}+\mathrm{G}$ ) were designed based on the conserved domain of SPS genes from other plants in GenBank. Reverse transcriptase-polymerase chain reaction (RT-PCR) was performed according to the protocol of the RNA PCR Kit (AMV) (version 3.0; TaKaRa Bio). The first cDNA was synthesized by reverse transcription using reverse transcriptase with $1 \mu \mathrm{g}$ RNA as template and with Oligo (dT)-Adaptor primer as first strand primer. The RT reaction program is $42^{\circ} \mathrm{C}$ for $30 \mathrm{~min}, 99^{\circ} \mathrm{C}$ for $5 \mathrm{~min}$, and $5{ }^{\circ} \mathrm{C}$ for $5 \mathrm{~min}, 1$ cycle. PCR was performed by running the following program: $94{ }^{\circ} \mathrm{C}$ predenature for $5 \mathrm{~min}$; $94{ }^{\circ} \mathrm{C}$ for $1 \mathrm{~min}, 53{ }^{\circ} \mathrm{C}$ for $1 \mathrm{~min}$, and $72{ }^{\circ} \mathrm{C}$ for $3 \mathrm{~min}, 30$ cycles; and, $72{ }^{\circ} \mathrm{C}$ for $10 \mathrm{~min}$. The PCR product was separated by electrophoresis in $1.0 \%$ agarose gel. The isolation fragment was cloned by using PMD18-T vector (TaKaRa Bio) for sequencing.

A total of $1 \mu \mathrm{g}$ RNA from muskmelon fruit was taken to convert mRNAs into cDNAs using a 3' RACE kit (TaKaRa Bio) provided with AMV RT and a universal oligo (dT) containing adapter primer (5'-CTGATCTAGAGGTACCG GATCCT $_{17-3^{\prime}}$ ). The partial CmSPS1 gene from the $3^{\prime}$ end was then amplified by a pair of PCR primers: the gene specific forward primer 1 (5'-AAGACTTTGGTGCGGTGGGCT GATC- $\left.3^{\prime}\right)$ and reverse primer $\left(5^{\prime}-\mathrm{CTGATCTAGAGG}\right.$ TACCGGATCC-3') provided with the kit. According to the manufacturer's instructions, PCR was performed under the following conditions: cDNA was denatured at $94{ }^{\circ} \mathrm{C}$ for $2 \mathrm{~min}$ followed by 35 cycles of amplification $\left(94^{\circ} \mathrm{C}\right.$ for $30 \mathrm{~s}, 55^{\circ} \mathrm{C}$ for $30 \mathrm{~s}$, and $72^{\circ} \mathrm{C}$ for $\left.1 \mathrm{~min}\right)$ and $7 \mathrm{~min}$ at $72^{\circ} \mathrm{C}$. The PCR product was purified and cloned into pMD18-T vector for sequencing.
Based on the sequence of the initial $C$. melo SPS gene, the specific primers 2, 3, and 4 (primer $25^{\prime}$-CCAGCGTGGTTGC CTTGGTTTGC-3', primer $35^{\prime}$-CTGCCTCA ATCAAAGTC AGTCCA-3', primer $45^{\prime}$-TACCCATTATCAAGGTTAGAT TAGC-3') were designed to amplify the $5^{\prime}$ end of CmSPS1 gene using the 5' RACE system for rapid amplification of cDNA ends (version 2.0; Invitrogen Corp., Carlsbad, CA). The 5' RACE was performed according to the manufacturer's instructions. The PCR product was purified and cloned into pMD18-T vector for sequencing. DNAman (version 4.0; Lynnon Biosoft, Quebec), ANTHEPROT (version 5.0; Deleage et al., 2001), and NCBI web were used to analyze the DNA and protein sequences.

NoRTHERN BLOT ANALYSIS. For RNA gel-blot analysis, $20 \mu \mathrm{g}$ of total RNA was separated on $1.2 \%$ agarose gels containing formaldehyde. RNA gel blot analysis was performed according to the DIG Northern Starter Kit Manual (Roche, Penzberg, Germany). 3' UTR fragment of CmSPS1 cDNA [ $\approx 300$ base pairs (bp)] was used as a probe labeled by digoxygenin. RNA transfer and fixation were performed by capillary transfer with $20 \times \mathrm{SSC}$ overnight and baking membrane at $80{ }^{\circ} \mathrm{C}$ for $2 \mathrm{~h}$. Prehybridization was done at $68^{\circ} \mathrm{C}$ in DIG Easy Hyb Buffer for 30 min with gentle agitation. Hybridization was carried out in the same buffer overnight at $68^{\circ} \mathrm{C}$. The blot was washed twice with $2 \times \mathrm{SSC}$ and $0.1 \%$ sodium dodecyl sulfate (SDS) at 15 to $25{ }^{\circ} \mathrm{C}$ under constant agitation for $5 \mathrm{~min}$. Then the blot was washed twice in $0.1 \times \mathrm{SSC}$ and $0.1 \% \mathrm{SDS}$ at $68^{\circ} \mathrm{C}$ under constant agitation for $15 \mathrm{~min}$. The hybridized probes are immunodetected with antidigoxigenin-AP, Fab fragments, and then visualized with the chemiluminescence substrate CDP-Star. Enzymatic dephosphorylation of CDP-Star by alkaline phosphatase leads to a light emission at a maximum wavelength of $465 \mathrm{~nm}$, which is recorded on x-ray films. Exposure time was $30 \mathrm{~min}$.

SuCrose Content measurement. Sucrose was extracted by grinding flesh tissues (10 $\mathrm{g}$ fresh weight) in $80 \%$ ethanol, adjusted to $\mathrm{pH} 7.0$ with $0.1 \mathrm{~N} \mathrm{NaOH}$, and heated for $5 \mathrm{~min}$ at $80^{\circ} \mathrm{C}$. The extraction was repeated three times and five fruit were used for each replicate. The extract corresponding to $0.5 \mathrm{~g}$ fresh weight was dried in vacuo and redissolved in water. An aliquot $(10 \mu \mathrm{L})$ of the eluate was analyzed by high-performance liquid chromatography (Shimadzu Corp.), which was equipped with a RID-10A detector and a SCL-10AVP data acquisition system.

SuCROSE PHOSPHATE SYNTHASE EXTRACTION AND ASSAY. Sucrose phosphate synthase extraction and assay were performed in a manner similar to that previously described by Lowell et al. (1989) and Hubbard et al. (1989) with some minor modifications. SPS was extracted from $\approx 1 \mathrm{~g}$ of minced frozen melon tissue by homogenizing for $1 \mathrm{~min}$ on ice in $200 \mathrm{~mm}$ Hepes/ $\mathrm{NaOH}$ ( $\mathrm{pH} 7.5), 5 \mathrm{~mm} \mathrm{MgCl} 2,1 \mathrm{~mm}$ EDTA, $0.5 \mathrm{mg} \cdot \mathrm{mL}^{-1}$ of BSA, 0.005\% Triton X-100 (Sigma-Aldrich Corp., St. Louis), $1 \mathrm{M} \mathrm{NaCl}, 1 \%$ insoluble PVP, and $5 \mathrm{~mm}$ DTT. Homogenates were quickly desalted at $4{ }^{\circ} \mathrm{C}$. Desalted buffer contained $20 \mathrm{~mm}$ Hepes/ $\mathrm{NaOH}(\mathrm{pH} 7.5), 0.25 \mathrm{~mm} \mathrm{MgCl}_{2}$, $0.01 \%$ 2-mercaptoethanol, $1 \mathrm{~mm}$ EDTA, 0.05\% BSA, 0.2\% glycerine. Desalted extract was assayed immediately.

Sucrose phosphate synthase assay contained $50 \mathrm{~mm}$ Hepes/ $\mathrm{NaOH}$ (pH 7.5), $15 \mathrm{~mm} \mathrm{MgCl}_{2}, 25$ mm Fru-6-P, 25 mм Glu-6-P, and $25 \mathrm{~mm}$ UDP-Glu. Control was boiled for $10 \mathrm{~min}$ immediately after the addition of the desalted enzyme extract. The reactions were incubated for $30 \mathrm{~min}$ at $37^{\circ} \mathrm{C}$ and then stopped by transfer to a boiling water bath. To the $70-\mu \mathrm{L}$ sample, $70 \mu \mathrm{L}$ 


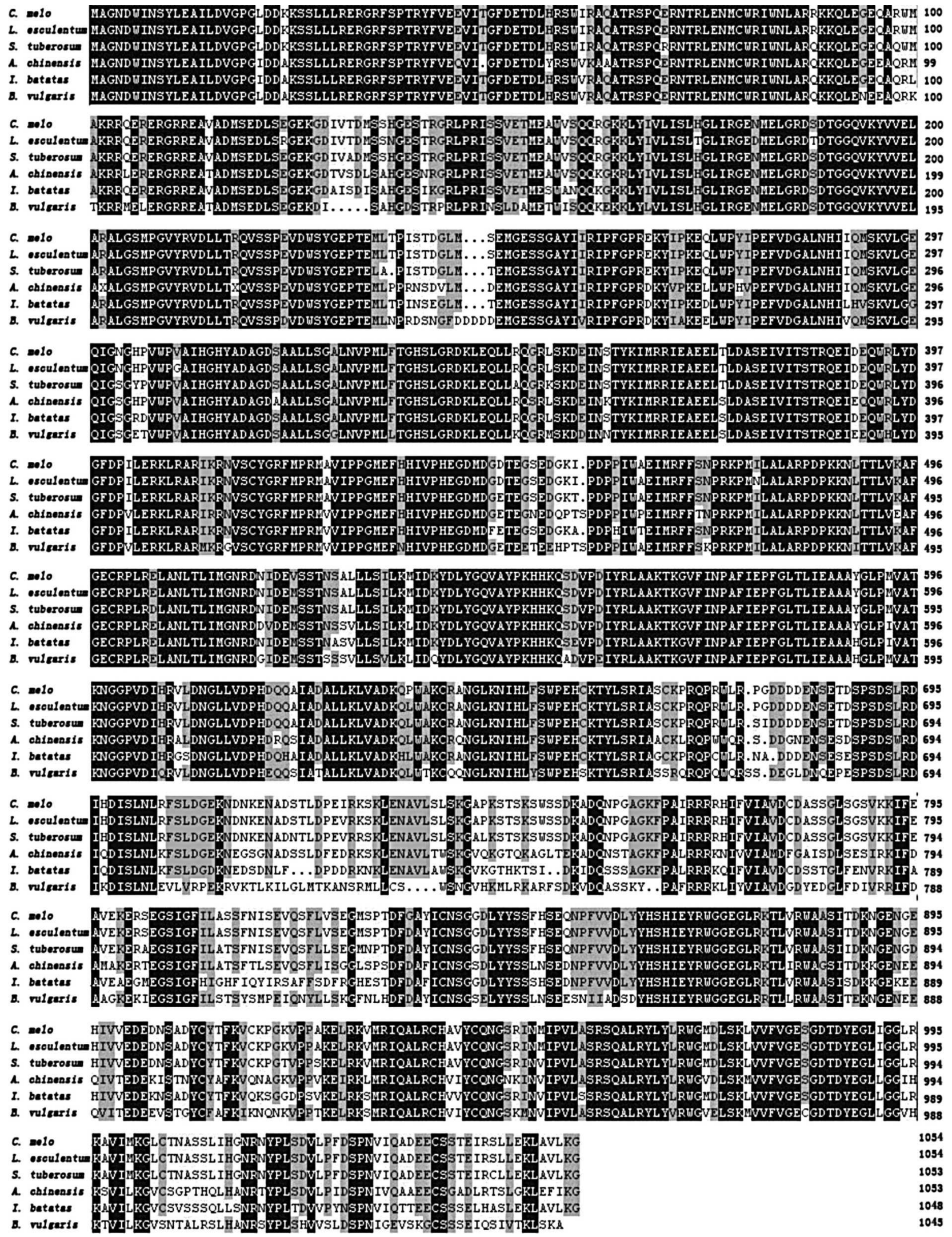

Fig. 1. Alignment of predicted amino acid sequences of sucrose phosphate synthase (SPS) genes from different plants. The GenBank accession numbers for the plant SPS sequences are: Cucumis melo ABF47344, Lycoperscicon esculentum AAU29197, Solanum tuberosum Q43845, Actinidia chinensis AAL86360, Ipomoea batatas AAL34531, and Beta vulgaris CAA57500. This alignment was produced using DNAman (version 4.0; Lynnon Biosoft, Quebec). Conserved residues are shaded in black. Dark gray shading indicates similar residues in five of six of the sequences and clear gray shading indicates similar residues in three of six of the sequences. 
of $30 \% \mathrm{NaOH}$ was added, boiled for $10 \mathrm{~min}$, and cooled. One milliliter anthrone reagent $\left(76 \mathrm{~mL}\right.$ of sulfuric acid, $30 \mathrm{~mL} \mathrm{H}_{2} \mathrm{O}$, and $150 \mathrm{mg}$ of anthrone) was then added, and the tubes were incubated for $20 \mathrm{~min}$ at $40^{\circ} \mathrm{C}$. Absorbance was measured with a microplate reader (model 3550-ultraviolet; Bio-Rad Laboratories, Hercules, CA) at $650 \mathrm{~nm}$ and compared with sucrose standards.

\section{Results}

Cloning and characterization of CMSPS1. To isolate SPS cDNA from muskmelon, we first designed a pair of degenerated primers according to the conserved domain of SPS amino acid sequences from other plant species. A 1408-bp cDNA fragment was amplified by RT-PCR. A 1600-bp and a 750-bp cDNA fragments were produced by 5' RACE and 3' RACE, respectively. After sequencing confirmation, a 3377-bp cDNA clone including a full-length coding region was isolated from muskmelon and named CmSPS1 (GenBank accession DQ521271). The deduced amino acid sequence of CmSPS1 contains 1054 amino acid residues with a predicted signal sequence cleavage site between residue 179 and residue 180 . The predicted mature protein might locate in the cytoplasm as a result of the mature protein without transmembrane regions. The alignment analysis showed that CmSPS1 shared with overall amino acid identities of $98.96 \%, 96.77 \%, 84.72 \%, 75.65 \%$, and $73.72 \%$ to tomato (Lycoperscicon esculentum L.), potato (Solanum tuberosum L.), kiwifruit (Actinidia chinensis Planch.), sweetpotato (Ipomoea batatas L.), and sugar beet (Beta vulgaris L.) SPS, respectively (Fig. 1).

CMSPS1 DIFFERENTIALLY EXPRESSED IN DIFFERENT MUSKMELON TISSUES. To determine the pattern of CmSPS1 expression in different muskmelon organs, a northern blot hybridization analysis was performed. The result showed that CmSPS1 transcripts are easily detected in the leaves, stems, and mature fruit, but cannot be detected at all in roots and flowers (Fig. 2), suggesting that CmSPS1 may play a role in leaf, stem, and fruit development in muskmelon.

REgULATION OF CMSPS1 MRNA ABUNDANCE DURING FRUIT DEVELOPMENT AND RIPENING. To further investigate the devel-

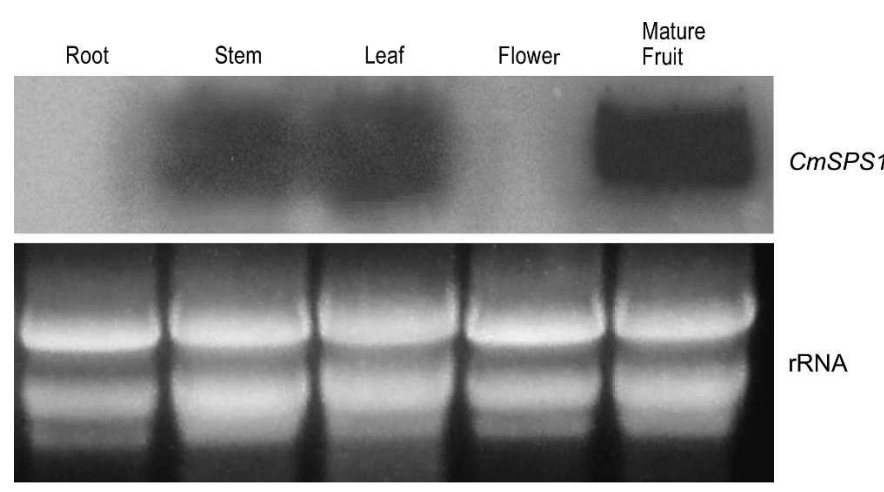

Fig. 2. RNA blot analysis of CmSPS1 spatial expression in muskmelon plants. Approximately $20 \mu \mathrm{g}$ of total RNA from root, stem, leaf, flower, and mature fruit of muskmelon inbred line M01-3 were separated on 1.2\% agarose gels containing formaldehyde. Root, stem, leaf, and flower tissues were harvested simultaneously from five 7- to 8-week-old plants and mature fruit were harvested as they mature from five 11- to 12-week-old plants. The blot was hybridized with a CmSPS1-specific probe. The ethidium bromide-stained rRNA band in the agarose gel is shown as a loading control.

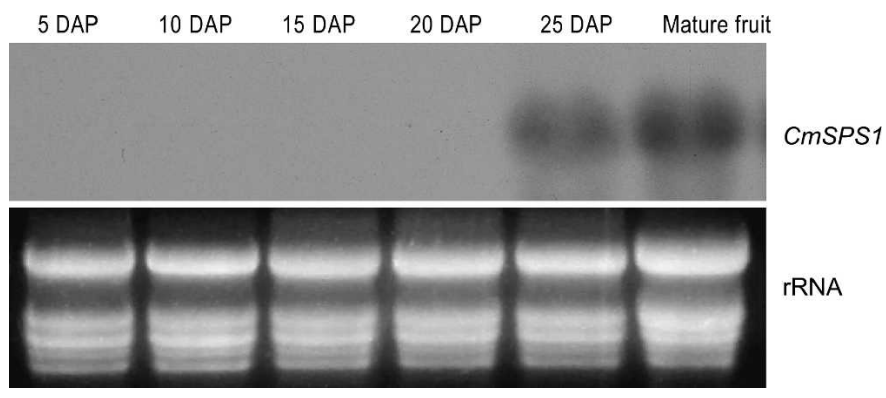

Fig. 3. RNA blot analysis of CmSPS1 expression in developmental muskmelon fruit. Approximately $20 \mu \mathrm{g}$ of total RNA from muskmelon inbred line M01-3 fruit of $5,10,15,20$, and $25 \mathrm{~d}$ after pollination (DAP) and mature fruit, respectively, were separated on $1.2 \%$ agarose gels containing formaldehyde. Five fruit of each stage were pooled to isolate RNA. The blot was hybridized with a CmSPS1-specific probe. The ethidium bromide-stained rRNA band in the agarose gel is shown as a loading control.

opmental regulation of CmSPS1 in fruit mesocarp tissues, a RNA blot analysis was carried out using different mesocarp tissues from 5 DAP to ripening. The result showed that CmSPS1 mRNA was not detected in the mesocarp tissues before 20 DAP. However, the CmSPS1 strongly expressed in the mesocarp tissues after 25 DAP, indicating that CmSPS1 may be involved in sucrose accumulation in fruit ripening in muskmelon (Fig. 3).

Sucrose CONTENT AND SUCrose Phosphate SyNThase ACTIVITY DURING FRUIT DEVELOPMENT AND RIPENING. To demonstrate the functions of CmSPS1 in regulating fruit quality, sucrose content and SPS activity were analyzed. The results showed that very low concentration of sucrose was detected in young and unripe muskmelons. However, a rapid accumulation of sucrose in fruit was observed between 20 and 30 DAP (Fig. 4A). Similarly, SPS activity showed a significant increase during the later stage of fruit development as well (Fig. 4B), indicating an essential role of SPS in sucrose metabolism in muskmelon fruit.

\section{Discussion}

SPS catalyzes net sucrose synthesis in plants and its activity is generally high in source tissues and low in sink organs (Huber and Huber, 1992). It has been proven that SPS activity can be a controlling factor for sucrose synthesis and also for photosynthesis (Shinano et al., 2006; Stitt et al., 1988; Zuniga-Feest et al., 2005).To increase photosynthesis and sucrose synthesis, Worrell et al. (1991) genetically manipulated tomatoes by overexpressing a maize (Zea mays L.) SPS cDNA under the control of the promoter of the small subunit of Rubisco from tobacco (Nicotiana tabacum L.). Several transgenic lines showed a higher SPS activity and higher sucrose level in their leaves than untransformed controls. Previous studies demonstrated that the SPS activity in transformed tomato leaves was six times greater than that of the controls. At low irradiances, no increase in net photosynthesis was observed, but the light- and $\mathrm{CO}_{2}$-saturated rates of photosynthesis in transformed leaves were increased by $\approx 20 \%$ (Galtier et al., 1993, 1995; Micallef et al., 1995). In this study, we demonstrated that CmSPS1 was expressed in stem and leaf but not in root and flower tissues, implying that CmSPS1 may be also involved in sucrose synthesis and photosynthesis in muskmelon. Langenkämper et al. (2002) reported that there were at least three families of 

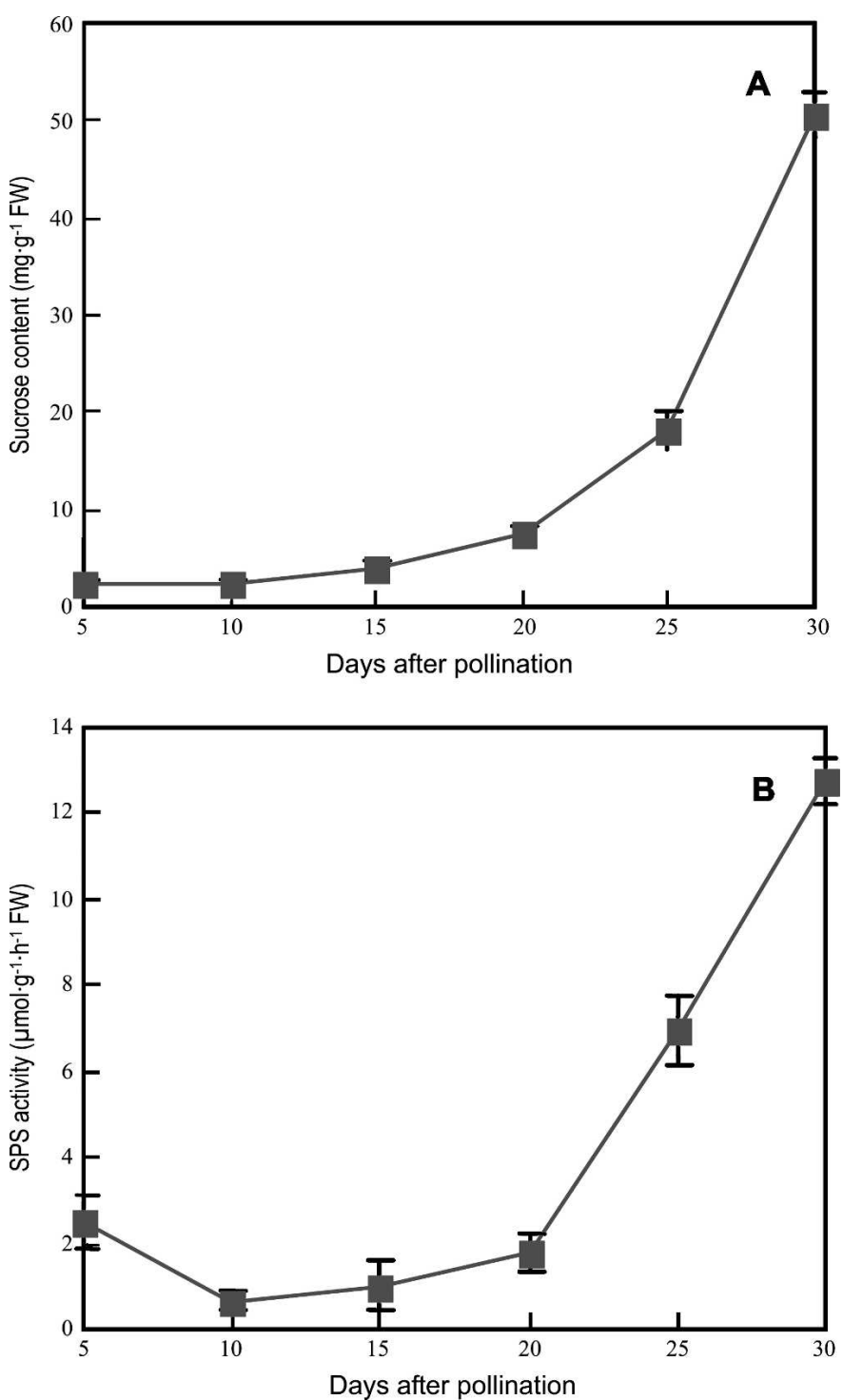

Fig. 4. Sucrose content and sucrose phosphate synthase (SPS) activity during M01-3 muskmelon fruit development. Five, 10, 15, 20, 25, and $30 \mathrm{~d}$ after pollination (DAP) fruit were harvested, respectively. Thirty DAP is considered commercial maturity. The SPS activity assays and sucrose determination were carried out on duplicated samples. The experiments were repeated three times and five fruit were used for each replicate. (A) Sucrose content during M01-3 muskmelon fruit development; (B) SPS activity during M01-3 muskmelon fruit development. Bars indicate SE.

SPS genes, designated A, B, and C based on the SPS genes isolated from Arabidopsis and other plant species. Recently, Castleden et al. (2004) revealed the finding of five families of SPS genes in wheat (Triticum aestivum L.) and other monocotyledonous plants from the family Poaceae (grasses). Each of the SPS gene families in wheat showed different, but overlapping, spatial and temporal expression patterns, and in most organs at least two different SPS genes are expressed. In this study, we cloned and characterized a SPS gene from muskmelon, CmSPS1. However, it is not clear how many SPS genes exist in muskmelon. We are constructing cDNA libraries from muskmelon leaf and fruit and try to isolate other SPS gene members involved in sucrose synthesis or photosynthesis in muskmelon by screening the cDNA libraries.
Sucrose phosphate synthase activity has been suggested to determine the rate of sucrose synthesis and the level of sucrose accumulation in late fruit development of various plant species such as tomato (Dali et al., 1992; Miron and Schaffer, 1991), muskmelon (Hubbard et al., 1989; Lingle and Dunlap, 1987), banana (Musa acuminate L.) (Hubbard et al., 1990), asian pear 'Chojuro' [Pyrus pyrifolia (Burm.f.) Nakai] and 'Yali' ( $P$. bretschneideri Rehd.) (Moriguchi et al., 1992), peach [Prunus persica (L.) Batsch], strawberry (Fragaria $\times$ ananassa Duch.), kiwi (Actinidia deliciosa A. Chev.), and mango (Mangifera indica L.) (Hubbard et al., 1991). Recently, SPS-encoding genes have been isolated and characterized from some higher plant species (Hesse et al., 1995; Hubbard et al., 1991; Huber and Huber, 1996). To date, however, there have been only a few studies of SPS gene expression in relation to fruit tissues. Nascimanto et al. (1997) reported that the accumulation of sucrose occurred $4 \mathrm{~d}$ after SPS mRNA and activity had reached their maxima during banana fruit ripening. In citrus (Citrus unshiu Marc.), the levels of CitSPS1 mRNA in immature fruit were low but very high in mature fruit (Komatsu et al., 1996). The SPS-antisense potato transformants showed a reduced expression of sucrose-phosphate synthase, which led to inhibition of sucrose synthesis in tuber discs (Geigenberger et al., 1999). Our present results showed that the CmSPS1 transcripts were not detected in the young muskmelon fruit but rapid accumulation in the mature fruit (Fig. 3). This pattern of CmSPS1 expression in mesocarp tissues is in accordance with the alteration of SPS activity and sucrose accumulation during fruit development of muskmelon (Fig. 4). Taken together, these data led us to conclude that the sucrose content in plant sink organs is regulated by the level of SPS expression. Therefore, increasing SPS expression might be an important regulatory event of sweetening during melon fruit ripening. Currently, we are overexpressing CmSPS1 under the control of a fruit-specific promoter, which will help reveal the potential application of CmSPS1 in controlling the quality of muskmelon fruit.

\section{Literature Cited}

Castleden, C.K., N. Aoli, V.J. Gillespie, E.A. MacRae, W.P. Quick, P. Buchner, C.H. Foyer, R.T. Furbank, and J.E. Lunn. 2004. Evolution and function of the sucrose-phosphate synthase gene families in wheat and other grasses. Plant Physiol. 135:1753-1764.

Dali, N., D. Michaud, and S. Yelle. 1992. Evidence for the involvement of sucrose phosphate synthase in the pathway of sugar accumulation in sucrose-accumulating tomato fruits. Plant Physiol. 99:434-438.

Deleage, G., C. Combet, C. Blanchet, and C. Geourjon. 2001. ANTHEPROT: An integrated protein sequence analysis software with client/server capabilities. Comput. Biol. Med. 31:259-267.

Galtier, N., C.H. Foyer, J. Huber, T.A. Voelker, and S.C. Huber. 1993. Effects of elevated sucrose-phosphate synthase activity on photosynthesis, assimilate partitioning, and growth in tomato (Lycopersicon esculentum var. UC82B). Plant Physiol. 101:535-543.

Galtier, N., C.H. Foyer, E. Murchie, R. Alred, P. Ouick, T.A. Voelker, C. Thepenier, G. Lasceve, and T. Betsche. 1995. Effects of light and atmospheric carbon dioxide enrichment on photosynthesis and carbon partitioning in the leaves of tomato (Lycopersicon esculentum L.) plants overexpression sucrose phosphate synthase. J. Expt. Bot. 46:1335-1344.

Geigenberger, P., R. Reimholz, U. Deiting, U. Sonnewald, and M. Stitt. 1999. Decrease expression of sucrose phosphate synthase strongly inhibits the water stress-induced synthesis of sucrose in growing potato tubers. Plant J. 19:119-129. 
Geromel, C., L.P. Ferreira, S.M.C. Guerreiro, A.A. Cavalari, D. Pot, L.F.P. Pereira, T. Leroy, L.G.E. Viera, P. Mazzafera, and P. Marraccini. 2006. Biochemical and genomic analysis of sucrose metabolism during coffee (Coffea arabica) fruit development. J. Expt. Bot. 57:3243-3258.

Hesse, H., U. Sonnewald, and L. Willmitzer. 1995. Cloning and expression analysis of sucrose phosphate synthase from sugar beet. Mol. Gen. Genet. 247:515-520.

Hubbard, N.L., S.C. Huber, and D.M. Pharr. 1989. Sucrose phosphate synthase and acid invertase as determinants of sucrose concentration in developing muskmelon (Cucumis melo L.) fruits. Plant Physiol. 91:1527-1534.

Hubbard, N.L., D.M. Phar, and S.C. Huber. 1990. Role of sucrose phosphate synthase in sucrose biosynthesis in ripening bananas and its relationship to the respiratory climacteric. Plant Physiol. 94: 201-208.

Hubbard, N.L., D.M. Pharr, and S.C. Huber. 1991. Sucrose phosphate synthase and other sucrose metabolizing enzymes in fruits of various species. Physiol. Plant. 82:191-196.

Huber, S.C. and J.L. Huber. 1992. Role of sucrose phosphate synthase in sucrose metabolism in leaves. Plant Physiol. 99:1275-1278.

Huber, S.C. and J.L. Huber. 1996. Role and regulation sucrose phosphate synthase in higher plants. Annu. Rev. Plant Mol. Biol. 47:431-445.

Komatsu, A., Y. Takanokura, T. Akihama, and M. Omura. 1996. Cloning and molecular analysis of cDNAs encoding three sucrose phosphate synthase isoforms from a citrus fruit (Citrus unshiu Marc.). Mol. Gen. Genet. 252:346-351.

Langenkämper, G., R.W.M. Fung, R.D. Newcomb, R.G. Atkinson, R.C. Gardner, and E.A. MacRae. 2002. Sucrose phosphate synthase genes in plants belong to three different families. J. Mol. Evol. 54:322-332.

Lester, G.E. and J.R. Dunlap. 1985. Physiological changes during development and ripening of 'Perlita' muskmelon fruits. Scientia Hort. 26:323-331.

Li, C.R., X.B. Zhang, and C.S. Hew. 2003. Cloning of a sucrose phosphate synthase gene highly expressed in flowers from the tropical epiphytic orchid oncidium goldiana. J. Expt. Bot. 54: 2189-2191.

Lingle, S.E. and J.R. Dunlap. 1987. Sucrose metabolism in netted muskmelon fruit during development. Plant Physiol. 84:386-389.

Lowell, C.A., P.T. Tomlinson, and K.E. Koch. 1989. Sucrose metabolizing enzymes in transport tissues and adjacent sink structures in developing citrus fruit. Plant Physiol. 90:1394-1402.
McCollum, T.G., D.J. Huber, and D.J. Cantliffe. 1988. Soluble sugar accumulation and activity of related enzymes during muskmelon fruit development. J. Amer. Soc. Hort. Sci. 113:399-403.

Micallef, B.J., K.A. Haskins, P.J. Vanderveer, K.-S. Roh, C.K. Shewmaker, and T.D. Sharkey. 1995. Altered photosynthesis, flowering, and fruiting in transgenic tomato plants that have an increased capacity for sucrose synthesis. Planta 196:327-334.

Miron, D. and A.A. Schaffer. 1991. Sucrose phosphate synthase, sucrose synthase, and invertase activities in developing fruit of Lycopersicon esculentum Mill. and sucrose accumulating Lycopersicon hirsutum Humb. and Bonpl. Plant Physiol. 95:623-627.

Moriguchi, T., K. Abe, T. Sanada, and S. Yamaki. 1992. Levels and role of sucrose synthase, sucrose-phosphate synthase, and acid invertase in sucrose accumulation in fruit of asian pear. J. Amer. Soc. Hort. Sci. 117:274-278.

Nascimanto, J.R., B.R. Cordenunsi, F.M. Lajolo, and M.J. Alcocer. 1997. Banana sucrose-phosphate synthase gene expression during fruit ripening. Planta 203:283-288.

Sakalo, V.D. and V.M. Kurchii. 2004. Hormonal control of sucrose phosphate synthase and sucrose synthase in sugar beet. Russ. J. Plant Physiol. 51:183-188.

Sambrook, J., E.F. Fritsch, and T. Maniatis. 1989. Molecular cloning: A laboratory manual. Cold Spring Harbor Laboratory Press, Cold Spring Harbor, NY.

Schaffer, A.A., B. Aloni, and E. Fogelman. 1987. Sucrose metabolism and accumulation in developing fruit of Cucumis. Phytochemistry 26:1883-1887.

Shinano, T., K. Ando, K. Okazaki, and M. Osaki. 2006. Developmental changes of plant affecting primary photosynthate distribution in rice leaves. Photosynthetica 44:591-598.

Stitt, M., I. Wilke, R. Feil, and H.W. Heldt. 1988. Coarse control of sucrose phosphate synthase in leaves: Alteration of the kinetic properties in the response to the rate of photosynthesis and the accumulation of sucrose. Planta 174:217-230.

Winter, H. and S.C. Huber. 2000. Regulation of sucrose metabolism in higher plants: Localization and regulation of activity of key enzymes. J. Crit. Rev. Biochem. Mol. Biol. 35:253-289.

Worrell, A.C., J.M. Bruneau, K. Summerfelt, M. Boersig, and T.A. Voelker. 1991. Expression of maize sucrose phosphate synthase in tomato alters leaf carbohydrate partitioning. Plant Cell 3:1121-1130.

Zuniga-Feest, A., D.R. Ort, A. Gutierrez, M. Gidekel, L.A. Bravo, and L. Corcuera. 2005. Light regulation of sucrose-phosphate synthase activity in the freezing-tolerant grass Deschampsia antarctica. Photosyn. Res. 83:75-86. 